\title{
"KING OF THE FOUR REGIONS" IN THE DYNASTY OF AKKADE
}

\section{TOHRU MAEDA*}

1. Year formulae were used continually from the Early Dynastic period to the Old Babylonian period. Year formulae used before the reign of Naram-Sin of Akkade have only been found in Nippur up to now.(1)

$\begin{array}{lll}\begin{array}{l}\text { Enšakušanna } \\ \text { Lugalzagesi }\end{array} & \begin{array}{l}\text { lugal-kalam-ma } \\ \text { lugal-kalam-ma } \\ \text { Sargon }\end{array} & \begin{array}{l}\text { Nippur } \\ \text { Nippur } \\ \text { lugal-kiŠ }\end{array} \\ \text { Rimuš } & \text { lugal-KIŠ } & \text { Nippur } \\ \text { Naram-Sin } & \text { šar kibrātim arba'im } & \text { Nippur } \\ & & \begin{array}{l}\text { Nippur, Lagaš, Adab, } \\ \text { Tutub, Mugdan. }\end{array}\end{array}$

Rimuš's year formula can only be assumed to have existed. There is no year formula that is confirmed for Maništusu. Lugalzagesi dated his reign by means of mu-itu in Umma.(2) It is not a mere coincidence that the tablets unearthed by expeditions in modern times which contain the year formulae of rulers before Naram-Sin are restricted to those tablets taken from Nippur.

Changes in the above table are made on the basis of royal titles which the rulers proclaimed.

\begin{tabular}{|c|c|}
\hline lugal-kišsi & none \\
\hline $\begin{array}{l}\text { lugal-kalam-ma } \\
\text { lugal-KIŠ }\end{array}$ & Nippur \\
\hline
\end{tabular}

As I argued in a previous paper, (3) the royal title "king of the city Kish (lugal-kiš ${ }^{\mathbf{k i}}$ )" characterized a ruler's own personal greatness; one who was able to defeat the enemy in other lands, but not in the Sumerian country

* Assistant Professor, Waseda University. 
itself, and was used as a symbol for the mighty ruler who could exert his power during conflicts between city-states. At this stage of the development of royal titles, year formulae did not appear. Year formulae began to be used when the royal title "king of the Land (lugal-kalam-ma)" appeared; the first title expressing sovereignty over an area larger than separate city-states and later succeeded by the title "king of KIS (lugal-KIS)" of Akkadian rulers. At this stage the year formulae were written on the tablets from Nippur, but not those from other cities. Naram-Sin proclaimed his title as "king of the four regions (šar kibrātim arba'im)," and at the same time he used year formulae in the cities under his control.

Changes in the development of the royal titles and the use of the year formulae were concurrent. These changes seem to have been influenced by the development of the idea of kingship. In this paper I wish to study how political ideology differed between the first rulers of Akkade, Sargon, Rimuš and Maništusu, who had the royal title "king of KIŠ," and Naram-Sin whose title was "king of the four regions." In light of my conclusions concerning this question, I will also examin what the different socio-political functions of the year formulae were between the two periods.

I will begin with an examination of the following three items:

1. the regions against which military expeditions were made,

2. domain which rulers proclaimed as their own,

3. god's conferment of the royal titles recorded in royal inscriptions.

\section{Military Expeditions}

As recorded in royal inscriptions and contemporary materials, the rulers of Akkade, Sargon, Rimuš, Maništusu and Naram-Sin, made expeditions against many areas.(4)

\begin{tabular}{ll}
\multicolumn{1}{c}{ Sargon } \\
Sumer (Uruk, Ur, Umma, Lagaš) & b $1=6,2=13,4,8,12$, \\
Elam & b 9, c (=year formulae), \\
Simurum & c. \\
Mari & b $1=6$, Westenholz OSP 1 \\
& (=year formula)
\end{tabular}


Rimuš

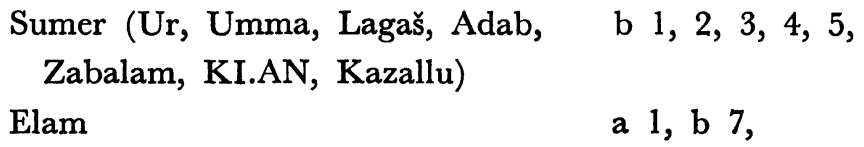

Maništusu

Anšan

a 1, b 1 ,

Naram-Sin

Sumer (Umma) b 2,

Magan a 2, 5,

Elam

b 4, Lambert OrNS 37,

Simurum

c, Cohen JCS 28 (=year formula),

Lulubum

a 1

Subir

b 4, Foster $A S J 4$ (=year formula),

Armanum, Ebla, Amanum

a 6, b 5, Lambert OrNS 37.

Sargon conquered Sumer and regions around Sumer and Akkade, Elam, Simurum and Mari. Rimuš supressed the revolt of the Sumerian cities and obtained suzerainty over the country of Elam. Maništusu told about his long campaign to Anšan. Rimuš and Maništusu did not record military expeditions against the western and northern regions. However, Naram-Sin made many vigorous campaigns and reached the distant countries of Magan in the east, and Amanum, Subartu and Lulubum in the north-west.

The following are more details of their military expeditions against three regions, Sumer, Elam, and Ebla and Amanum.

\section{Sumer}

Sargon was a prominant king in the history of the conquest of Sumer.

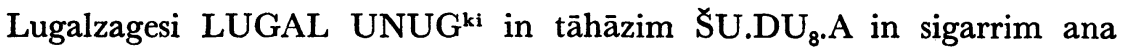
KÁ-d Enlil uruš

"He captured Lugalzagesi, the king of Uruk, in battle and led him in a neckstock to the gate of the god Enlil."

Sargon b 1 II 20-28

He obtained suzerainty of Sumer in place of Lugalzagesi and realized the Vol. XX 1984 
unification of Sumer and Akkade. He wished to govern Sumerian cities directly.

ištumma tiāmtim šapiltim mârū Agade ENSfkuatim ukâlū "From (the territory of) the sea below (to the Akkade) the sons of Akkade held the ensi-ship."

Sargon b 1 IV 12-19

However, it is very doubtful that Sargon authorized Akkadians as the governors of Sumerian cities, since the names of the governors who revolted against Rimuš at the beginning of his reign were Sumerians, not Akkadians: Ka-kù of Ur (b 1, 2), Ki-ku-íd of Lagaš (b 2, 5), Mes-ki-gal-la of Adab (b 4, 5), Lugal-ušumgal of Zabalam (b 4), and Lugal- $e_{11}$ of KI. AN (b 5).

Rimuš ruthlessly crushed the revolt of the Sumerian cities.

Rimuš LUGAL-KIŠ in tāhāzim Uríki [ ] u UB. MEki iš'ar u 8040 GURUŠ ušamqit $5460 \mathrm{LU}+\mathrm{SU}$ SU. $\mathrm{DU}_{8}$. A , u âlšuni SAG. GIŠ. RA u dûršuni İ. GUL. GUL $u$ in âlišuni 5984 GURUŠ ušuṣi'amma ana karāšim iškun

"Rimuš, the king of KIS, vanquished the men of Ur, [ ] and Umma in battle and killed 8040 men (and) captured 5460 prisoners of war, and he conquered their cities and broke their walls down and caused 5984 men to go out from the cities and placed them in the camp."

Rimuš b 2 XIX 12-48

In carrying out this campaign, he accomplished his purpose of depriving Sumerian cities of their independence and establishing his rule over Sumer. Since Maništusu, the king following Rimuš, did not record the revolt of any Sumerian cities, Rimušs strategy seems to have succeeded.

Although Naram-Sin recorded a battle against Umma in the first half of his reign when he had not yet been deified, Umma seems to have revolted against Akkade by taking advantage of the political instability created when Naram-Sin succeeded to the throne, in the same way the Sumerian cities revolted at the time of Rimuš's succession to the throne __, Akkadian rulers beginning with Rimuš kept stable lordship over Sumer throughout almost all other periods. 
Elam

Sargon conquered the country of Elam and received their tribute (Sargon b 11). At this time, there were two rulers designated by the Sumerian word lugal, lugal-NIM ${ }^{\mathbf{k i}}$ and lugal-Barahsi ${ }^{\mathbf{k} \mathbf{i}}$. Rimuš killed the ruler of Barahsi and he wrote:

\section{SUHUŠ Barahsiki in UN NIM ${ }^{\mathbf{k i}}$ issuhma Rimuš LUGAL-KIS NIM ibēl \\ 'He eradicated the 'foundation' of Barahsi from the people of Elam. Rimuš, the king of KIS, ruled over the land of Elam." \\ Rimuš b 7 XXIII $31-40=$ b 11 XXV 62-XXVI 8}

Since he does not indicate the name of the ruler of Elam, the authority of the ruler must have already broken down, and Barahsi controlled all Elam. In this political situation Rimuš destroyed the ruler of Barahsi and obtained suzerainty over the land of Elam.

In the reign of the next ruler, Maništusu, the governor of Elam obeyed him.

Maništusu LUGAL-KIŠ Ešpum İR. ZU ana dNarundi išruk

"For Maništusu, the king of KIŠ, Ešpum, his servant, dedicated (this statue) to the god Narundi."

\section{Maništusu d 2}

Akkade enjoyed the political stability of Elam. Maništusu used Elam as a military base, conquered Anšan, and made more distant expedition.

tiāmtim šapiltim MÁ. MÁ GIŠ. LA-e ušabir URU. KI URU. KI abarti tiāmtim 32 ana tāhāzim iphurūnimma SAG. GIŠ. RA

"He crossed the sea below with boats and defeated 32 cities of the other side which came together in battle."

Maništusu b 1 XXVI $37-47$

Naram-Sin made more long distance expeditions to Magan and dedicated Magan's booty to the got Enlil (Naram-Sin a 5).

The main purpose of the expeditions to the eastern area, Elam, Anšan and Magan, was to keep the trade route of the Persian Gulf open. Sargon Vol. XX 1984 
declared just after the conquest of Sumer;

MÁ-Meluhha ${ }^{k i}$ MÁ-Makan ${ }^{k i}$ MÁ-Tilmunki in kārim ši Agade ${ }^{k i}$ ikrus "He made the ships of Meluhha, Magan and Dilmun moor alongside the quay of Akkade."

Sargon b 2 VI $10-16$

But that seems not to be the only purpose for their expeditions. Since Elam invaded Mesopotamia frequently from the Early Dynastic period onward, it was a neccessary prerequisite for the political stability of Sumer and Akkade that they gain ascendancy over Elam.

\section{Ebla and Amanum}

Sargon wrote,

SAR. RU. GI LUGAL in Tutuliki ana dDagan uškên ikrub mātim alïtam iddissum Mariam ${ }^{\mathbf{k i}}$ Iarmutam $^{\mathbf{k}}$ Ebla $^{\mathbf{k i}}$ adima GIŠ. TIR GIŠ. ERIN u KUR. KUR. KU

"Sargon, the king, prostrated himself before the god Dagan and made supplication in the city Tutul. He gave him the upper land: Mari, Yarmuti, Ebla up to the Cedar Forest and the Silver mountains."

Sargon b 2 VI 17-35

He remarked only about his earnest prayers to the god Dagan in Tutul, but does not mention his military expeditions to Ebla.

Naram-Sin was able to declare publicly as follows:

ša ištum dâr šikitti nišē šar in šarri manāma $\operatorname{Armanam}^{k i}$ u Eblaki la ušalpitu, — , 'Naram- ${ }^{\mathrm{d}}$ Suen dannum Armanam $^{\mathrm{ki}}$ u Ebla ${ }^{\mathrm{ki}}$ in'ar, - u Amanam šadū GIŠ.ERIN igmur

"Since the time of the creation of people none among the kings ever reached Armanum and Ebla. - Naram-Sin, the mighty, conquered Armanum and Ebla, —, and controlled Amanum and the Cedar Mountain."

Naram-Sin b 5 I 1-II 28 
"KING OF THE FOUR REGIONS" IN THE DYNASTY OF AKKADE

He did not cite the activity of Sargon, his grandfather, but rather he declared himself to be the first king to conquer Ebla and Amanum. He also wrote,

ENSf. ENSf SUUBUR ${ }^{k i} \times u$ EN.EN aliātim NIDBA-su mahrišu ušarbibū.

"Rulers of Subar and governors of the High Land brought presents to him."

Naram-Sin b 4 II $14-21$

According to these records, it can be assumed that Naram-Sin made the first military expeditions to these countries.

Later rulers' records remain concerning the area mentioned above.

kur-gišerin-na lú-nu- $\mathrm{ku}_{4}-\mathrm{ku}_{4}$-da gù-dé-a en- ${ }^{\mathrm{d}}$ nin-gír-su-ke ${ }_{4}$ gír mu-nani-gar

"No one had ever entered the Cedar mountain. However, for Gudea, the god Ningirsu, the lord, opened roads there."

Gudea Cyl. A XV 19-21

ša ištu ûm șât ālam Mariki ilum ibnu LUGAL namman wašib Mariki tiāmtam la ikšudu KUR-GIŠ. ERIN u GIŠ. KU šadî rabûtim la ikšudu $\mathrm{u}$ iș̣išum la ikkisu $\mathrm{m}$ Jahdun-lim mâr Jaggid-lim LUGAL gašrum rīm šarrē ina lê'ûtim u gāmrūtim ana kišād tiāmtim illikma

"Since the day of yore when the god built the city Mari, no kings residing at Mari had ever reached the sea, or ever reached the mountains of cedar and boxwood and the high mountains, or ever cut down their trees. However, Jahdun-lim, son of Jaggid-lim, the valiant king, wild bull among kings, went in power and strength as far as the coast of the sea."

Jahdun-lim(5)

It seems to be well known in those times that the mountains were hard to penetrate. Yahdun-lim's inscription is worth notice. He told only about the kings of Mari, but he made no mention of whether or not the other city rulers reached the mountains before him. He may have known about Naram- 
Sin's expedition against the mountain from reading historical documents or legendary literature.

Sargon's expeditions are summarized as chiefly against Sumer and regions around Sumer and Akkade, that is, Elam, Simurum and Mari, for the purpose of gaining stability for Sumer and Akkade. Rimuš and Maništusu limited their expeditions almost entirely to Sumer and Elam. However, Naram-Sin tried to conquer other people or barbarians who lived in very distant countries.

\section{Domain}

I will present a selection of sentences from the royal inscriptions with which the Akkadian rulers give a description of their own domains.

The following is an expression in one of Sargon's inscriptions:

tiāmtam alïtam $\mathrm{u}$ šapiltam ${ }^{\mathrm{d} E n l i l}$ iddinušum

"The god Enlil gave him (the entire territory) from the sea above to the sea below."

Sargon b 1 IV $1-12$

Similar expressions were used by the rulers before and after Sargon.

a-ab-ba-sig-ta!-ta idigna buranunna-bi a-ab-ba-igi-nim-ma-šè gìr-bi si e-na-sá

"From the sea below, along the Tigris and Euphrates to the sea above, the roads were straightened."

Lugalzagesi, $B E$ 1, 87, II 4-11

dnin-gír-su lugal-ki-ág-ni-e a-ab-ba-igi-nim-ta a-ab-ba-sig-ga-šē gìr-bi gál mu-na- $\operatorname{tag}_{4}$

"The god Ningirsu, the king who loved him, opened the roads from the sea above to sea below."

Gudea St. B, V 23-27

The expression "from the sea above to the sea below" or vice versa seems to be a set fromula which expressed a geographical view of the world as it was generally thought to exist. An important phrase in one of Sargon's inscrip- 
tions which expressed his political view of world is as follows:

ištumma tiāmtim šapiltim DUMU $\times$ Agade $^{\mathbf{k i}}$ ENSf $^{\text {kuatim }}$ ukâlū Mariki u NIM $^{k i}$ mahriš SAR.RU.GI LUGAL-KALAM-MA ${ }^{k i}$ izazzūni

"From the sea below (to the land of Akkade), the sons of Akkade held the ensi-ship. (The men of) Mari and Elam stood before Sargon, the king of the Land, in order to swear allegiance."

Sargon b 1 IV 13-26

This phrase indicates that after his military compaigns Sargon gained Sumer and expanded his ruling zone from Elam in the east to Mari in the west. Rimuš wrote in his inscription;

Rimuš LUGAL-KIŠ šu dEnlil KALAM-MA ${ }^{\mathbf{k i}}$ kalama iddissum tiāmtam alītam šupiltam $u$ šadê kalašunuma ana dEnlil ukâl

"Rimuš, the king of KIS, to whom the god Enlil gave the whole (?) land, held (the entire territory) from the sea above to the sea below and all the mountains for the god Enlil's benefit."

Rimuš b 9 XXV x+1-16

This inscription also has as its core the formula "from the sea above to the sea below." Rimuš declared with this phrase that he took over Sargon's domain, although "all the mountains" seems to designate the acquisition of Assur.

There is no such example from Maništusu.

Naram-Sin proclaimed himself:

šapir KIŠ MI +x KALAM NIM ${ }^{\mathbf{k}}$ kališama adima Barahsi ${ }^{\mathbf{k}}$ u KALAM SUBIR $^{\mathbf{k} i}$ adima GLS.TIR GIŠ.ERIN

"The commander of ?, all Elam as far as Barahsi, and Subartu as far as the Cedar Forest."

Naram-Sin b 4 I 4-16

He also wrote about himself:

SAG.GIŠ.RA Armanim ${ }^{k i}$ u Ebla E $^{k i}$ NIM $^{k i}$ 
"The conqueror of Armanum, Ebla and Elam."

Naram-Sin: Lambert OrNS 37, 8-13

These epithets are not empty boasts, but are true reflections of events, since it can be confirmed from his contemporary documents that he made expeditions to these countries. According to records of his military compaigns and royal epithets, Naram-Sin began in actuality to rule the area as far as the Mediterranean. Contrary to this, the sphere of influence of Sargon, Rimuš and perhaps Maništusu went only as far as Mari, though they proclaim that they had the dominion over the land "from the sea above to the sea below."

The area from Mari in the west to Elam in the east was a self-contained world in which the city-states had had warlike or peaceful political relations with each other since the Early Dynastic period, as Eannatum of Lagash recorded in his inscriptions. (6) Sargon wished to unite this "old world." This goal of political unification seemed to be more important to Sargon than military expansion over distant regions. However, Naram-Sin went beyond the "old world" and conquered distant regions.

It is important for the study of Akkadian frontiers to jot down on maps the places where contemporary materials were unearthed. These places are shown as follows:(7)

$\begin{array}{ll}\text { Sargon: } & \text { Nippur, Susa, } \\ \text { Rimuš: } & \text { Nippur, Ur, Uruk, Sippar, Girsu, Tutub, Assur, Tel Brak, } \\ \text { Maništusu: } & \text { Nippur, Sippar, Susa, Assur, Qamišliyyah, } \\ \text { Naram-Sin: } & \text { Nippur, Ur, Girsu, Adab, Tutub, Nineveh, Mugdan, } \\ & \text { Marada, Mari, Susa, Niqum, Tel Brak, Pir Hüseyin, } \\ & \text { Bassetki. }\end{array}$

Year formulae were written on the tablets from Nippur in the reigns of Sargon, Rimuš and Naram-Sin, while Naram-Sin's year formulae were written furthermore on the tablets from Girsu, Adab, Tutub and Mugdan. Governors of Susa and Assur called themselves servants of Maništusu. (8) The governor of Niqum called himself the servant of Naram-Sin.

ana ${ }^{\mathrm{d}} \mathrm{Aba}{ }^{\mathrm{d}}$ Naram- ${ }^{\mathrm{d}}$ Suen dannum LUGAL kibrātim arba'im SAG. GIŠ.RA Armanim ${ }^{k i}$ u Ebla $^{k i}$ u NIM $^{k i}$ karšum šu SUKKAL-li ENSf 


\section{Niqum $^{k i}$ ÌR.ZU}

"To the god Aba, Naram-Sin, the mighty, the king of the four regions, who conquered Armanum, Ebla and Elam, (dedicated it). Karšum, who is the sukkal and governor of Niqum, is his servant."

Naram-Sin: Lambert OrNS 37

${ }^{d}$ Naram- ${ }^{d}$ Suen dannum LUGAL kibrātim arba'im Karšum šu SUKKAL-li ENSf Niqum ${ }^{\mathrm{ki}}$ ÌR.ZU ana ${ }^{\mathrm{d}}$ Balih-ili A.MU.RU

"For Naram-Sin, the mighty, the king of the four regions, Karšum, who is sukkal and governor of Niqum and his servant, dedicated it to the god Balih-ili."

Naram-Sin: Dossin IrAn 2

Sons of Naram-Sin were granted the governorship of Marada and Tutu.

Naram- ${ }^{\mathrm{d}}$ Suen dannum LAGAL kibrātim arba'im —_, in ûmišu Lipit-ili DUMU.ZU ENSf Marada ${ }^{k i}$ É-d Lugal-marada in Marada $^{\mathbf{k i}}$ ibni

"For Naram-Sin, the mighty, the king of the four regions, —_, at that time Lipit-ili, his son, the governor of Marada, built the temple of the god Lugal-marada in the city of Marada."

Naram-Sin a 3

DUMU d Naram- ${ }^{d}$ Suen dannum Nabi-ulmaš ENSf Tutu ${ }^{k i}$ Lippuš-jaum BALAG.DI dSuen DUMU.Mf.ZU

"The son of Naram-Sin, who is the mighty, Nabi-ulmaš, the governor of Tutu; Lippuš-jaum, the singer of lamentations of the god Sin, is his daughter."

Naram-Sin Families 2

These year formulae and cylinder seals prove without a doubt that the cities where these materials were found were under Akkadian control. Assur, like Elam, had been within the realm of the Akkadian dynasty since the reign of Maništusu. Samši-Adad I of Assyria recorded in a later period, "the temple Emenue - which Maništusu, son of Sargon, the king of Akkade, had built."( $(9)$ Vases unearthed from Tutub and Tel Brak have inscriptions which 
recorded that Rimuš dedicated the booty of Elam to the god Enlil or Sin. These deities had little connection to the cities of Tutub and Tel Brak, but rather were related to Nippur and Ur where a vase and a mace-head which held the same inscriptions as on the former vases were found.

ana ${ }^{d}$ Enlil/ ${ }^{d}$ Suen Rimuš LUGAL-KIŠ inu Elam u Barahsi inâruni in NAM.RA.AK NIM ${ }^{\mathbf{k i}}$ A.MU.RU

"To the god Enlil/Sin, Rimuš, the king of KIŠ, when he defeated Elam and Barahsi, dedicated the booty of Elam."

Rimuš a 1 and 2

These materials would seem to show that Rimuš wished to have a stable trade route from Elam through the Diyala region and Assur to Anatolia, though there is room to speculate that a ruler after the reign of Rimuš brought the vases from Ur and Nippur to these cities.

At least it can be confirmed that Naram-Sin's inscriptions were unearthed in more places in the distant country than those of the former three rulers.

\section{Royal Titles}

As previously stated, Sargon called himself lugal-kalam-ma and lugal-KIŠ, and Rimuš and Maništusu succeeded to Sargon's title lugal-KIŠ. Naram-Sin began to use the title šar kibrātim arba'im.

Sargon divested Lugalzagesi of the title lugal-kalam-ma in the course of his triumph against him. Lugalzagesi was purposely not called by the title lugal-kalam-ma in Sargon's inscriptions, but named only "king of Uruk (lugal-

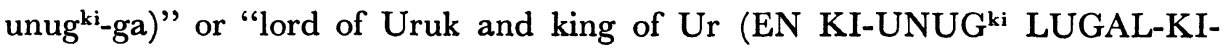
UR ${ }^{\mathrm{ki}}$ )," both which befitted the ruler of a city-state but were rather inferior titles compared to the title "king of the Land."

SAR.RU.GI LUGAL-KALAM-MA ${ }^{\mathbf{k i}}$ tiāmtam alītam $u$ šapiltam ${ }^{d}$ Enlil iddinušum

"To Sargon, the king of the Land, - the god Enlil gave him (the entire territory) from the sea above to the sea below."

Sargon b 1 IV 1-12 


\section{"KING OF THE FOUR REGIONS" IN THE DYNASTY OF AKKADE}

dEnlil tiāmtam alītam $u$ šapiltam iddissum SAR.RU.GI

\section{LUGAL-KIŠ [ ]}

"The god Enlil gave him (the entire territory) from the sea above to the sea below. Sargon, the king of KIS, [ ]."

Sargon b 10 XIII $1-16$

According to these inscriptions, "king of the land' and "king of KIŠ" are parallel titles, both indicating the idea of kingship as rule over the entire territory from the sea above to the sea below given by the god Enlil.

Rimuš LUGAL-KIŠ šu ${ }^{d}$ Enlil KALAM-MA ${ }^{\mathbf{k i}}$ kalama iddissum tiāmtam alītam šupiltam $u$ šadê kalašunuma ana dEnlil ukâl

"Rimuš, the king of KIS, to whom the god Enlil gave the whole(?) land, held (the entire territory) from the sea above to the sea below and all the mountains for the god Enlil's benefit."

Rimuš b 9 XXV x+1-16

Rimuš LUGAL-KIŠ zu ?-ra-ma šarrutam dEnlil iddinušum

"To Rimuš, the king of KIŠ, the god Enlil gave the kingship."

Rimuš b 1 XV 55-61

In the case of Rimuš, the title "king of KIŠ" has the same characteristics as when used with Sargon, that is, rule over the entire territory, and Enlil's conferment of the title.

I cannot cite any examples from Maništusu.

On the other hand, the title "king of the four regions" was not given to Naram-Sin by the god Enlil, but rather it was the goddess Inanna who was deeply connected with the royal title.

Naram-Sin dannum LUGAL-A.GA.DE ${ }^{\mathbf{k i}}$ inu kibrātum arba'um ištiniš ihanišu in rîmati dINANNA taramušu

"Naram-Sin, the king of Akkade; when the four regions were subdued together, in love of the goddess Inanna who loved him."

Naram-Sin: Al-Fouadi Sumer 32(10)

in šipri dINANNA GA-LUL-ma kibrātum arba'um ištiniš ihanišuma 


\section{imharūnim}

"By the command of the goddess Inanna, the —_, the four regions were subdued together and faced me."

Naram-Sin b 2 Rs(?) III $x+14-20$

The goddess Inanna ordered Naram-Sin to conquer the four insubordinant regions. In the Early Dynastic period, Inanna was closely related with the royal title "king of the city Kiš (lugal-kiški )." She gave the title to the rulers of Sumerian city-states. By means of this, Inanna gave them the power to overwhelm enemy lands. In the case of Naram-Sin, Inanna similarly granted him the power to conquer all the people in the world.

The god Enlil gave the title "king of the Land" and "king of KIS"' to the rulers with the expectation that they would maintain peace and order in the world which they had unified. For example, Rimuš stated that he actually held the entire territory from the sea above to the sea below and all the mountains for the god Enlil's benefit (Rimuš b $9 \mathrm{XXV}$ ).

In conclusion, the idea of kingship in the period from Sargon to Maništusu was in principle to unify Sumer and Akkade and to maintain peace and order in their domains under the protection of the god Enlil. On the other hand, we recongnize that through use of the title "king of the four regions" Naram-Sin was the first to employ the idea of kingship to gain mastery over the barbarians in distant countries and to execute a policy of military expansion ordered by the goddess Inanna. However, he never neglected the god Enlil, because he built the temple of the god Enlil in Nippur and told proudly about this activity in his inscriptions (Naram-Sin a 9 and 10). In general, there is a tendency of Sumerians and Akkadians never to neglect old ideas, but rather to incorporate old ideas with new ones in the development of different ideas.

5. In light of this study of military expeditions and royal titles, we can clarify the different ideas of kingship between the reigns of Sargon, Rimuš and Maništusu and the reign of Naram-Sin. This is illustrated as follows: 
periods

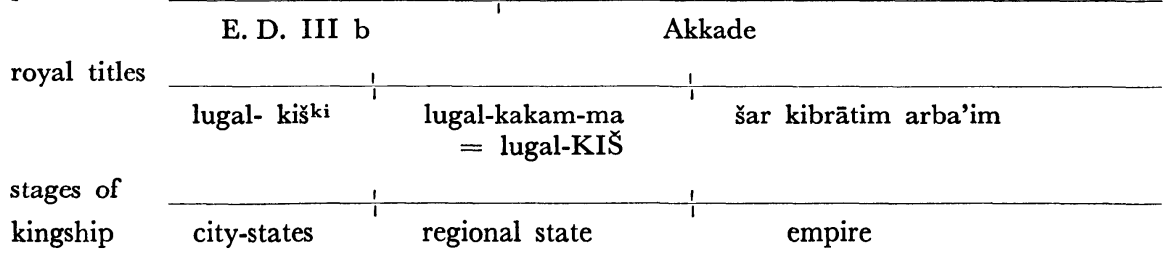

Although there are two periods recorded on the graph, the Early Dynastic period and Akkadian period, the development of the idea of kingship can be divided into three stages. The very end of the Early Dynastic period and the first half of the Akkadian period make up the same stage in the development of the idea of kingship. Since we can trace the continuity of the development of the idea of kingship, particularly in regards to the Akkadian rulers' acceptance of the idea of Sumerian rulers, it is not necessary to emphasize the influence of Semitic ideology on the development of imperialism as Vansiphout asserted.(11)

In Nippur rulers of regional states employed their year formulae as a mean by which rulers authorized by the god Enlil to govern the human world would have to report that they had performed their duties without mishap. This seems to show the rulers' piety for the god Enlil. On the other hand, NaramSin seemed to have forced the cities under his control to use his year formulae in order to flaunt his royal prerogatives. We can see a change in the idea of kingship from a pious king before the gods to the mighty king reigning over all people.

After the decline of the Akkadian monarchy, Gudea of Lagash, as well as rulers of many city-states after the period of the Ur III Dynasty, continued to use the year formulae even though they never had suzerainty over Sumer and Akkade. This phenomenon could be explained in the following way: a ruler who, recognizing himself as an independent ruler, flaunted his authority by using his year formulae. 


\section{Notes}

(1) For the texts, see A. Ungnad, Datenlisten, Reallexikon der Assyriologie II, 131-196, A. Westenholz, OSP I, 115-116, I. J. Gelb, MAD 2², 193-207, and H. Hirsch, Die Inschriften der Könige von Agade, AfO 20, 1-33.

( 2 ) G. G. Hackman, BIN 8. Gf. B. R. Foster, Umma in the Sargonic Period, Hamden 1982, and M. A. Powell, Texts from the Time of Lugalzagesi, HUCA 49, 1-58.

( 3 ) T. Maeda, "King of Kish" in Pre-Sargonic Sumer, Orient 17, 1-17.

(4) Category groupings are according to Hirsch, AfO 20; Further: Lambert OrNS $37=$ M. Lambert, Masses d'armes de pierre au nom de Naramsîn, OrNS 37, 85-86, Cohen JCS $28=$ M. E. Cohen, A new Naram-Sin date formula, JCS 28/4, 227-232, and Foster $A S J 4=$ B. R. Foster, An Agricultural Archive from Sargonic Akkad, Acta Sumerologica 4, 7-54.

( 5 ) G. Dossin, L'inscription de fondation de Iahdun-lim, roi de Mari, Syria 32, 1-28: I 34-II 9.

(6) Ean 2 etc. in E. Sollberger, CIRP, and H. Staible, Die Altsumerischen Bau- und Weihinschriften, Wiesbaden 1982.

( 7 ) See Gelb, $M A D 2^{2}$; Further, Dossin, IrAn 2, 159, Lambert OrNS 37, W. Nagel, $A P A$ 1, 195, and A. Al-Fouadi, Sumer 32, 63-75.

(8) See Gelb, MAD 2², 198: Officials 1 and 2.

(9) A. K. Grayson, Assyrian Royal Inscriptions I, Wiesbaden 1972, 23.

(10) See, however, T. Jacobsen, AfO 26, $12^{45}$.

(11) H. Vanstiphout, Political ideology in early Sumer, OLP 1, 23.

* Part of the results presented in this paper were from a study supported by a grant from Waseda University. 